\title{
Leucobacter chromiireducens subsp. solipictus subsp. nov., a pigmented bacterium isolated from the nematode Caenorhabditis elegans, and emended description of $L$. chromiireducens
}

\author{
Correspondence \\ Man-Wah Tan \\ mwtan@stanford.edu
}

\author{
Rachel E. Muir ${ }^{1}$ and Man-Wah $\operatorname{Tan}^{1,2}$ \\ 1Department of Genetics, Stanford University School of Medicine, Stanford, CA 94305-5120, USA \\ ${ }^{2}$ Department of Microbiology and Immunology, Stanford University School of Medicine, Stanford, \\ CA 94305-5120, USA
}

\begin{abstract}
A yellow-pigmented, Gram-positive, aerobic, non-motile, non-spore-forming, irregular rod-shaped bacterium (strain TAN $31504^{\top}$ ) was isolated from the bacteriophagous nematode Caenorhabditis elegans. Based on 16S rRNA gene sequence similarity, DNA G + C content of $69.5 \mathrm{~mol} \%$, 2,4-diaminobutyric acid in the cell-wall peptidoglycan, major menaquinone MK-11, abundance of anteiso- and iso-fatty acids, polar lipids diphosphatidylglycerol and phosphatidylglycerol and a number of shared biochemical characteristics, strain TAN $31504^{\top}$ was placed in the genus Leucobacter. DNA-DNA hybridization comparisons demonstrated a $91 \%$ DNA-DNA relatedness between strain TAN $31504^{\top}$ and Leucobacter chromiireducens LMG $22506^{\top}$ indicating that these two strains belong to the same species, when the recommended threshold value of $70 \%$ DNA-DNA relatedness for the definition of a bacterial species by the ad hoc committee on reconciliation of approaches to bacterial systematics is considered. Based on distinct differences in morphology, physiology, chemotaxonomic markers and various biochemical characteristics, it is proposed to split the species $L$. chromiireducens into two novel subspecies, Leucobacter chromiireducens subsp. chromiireducens subsp. nov. (type strain $\mathrm{L}-1^{\top}=\mathrm{CIP}$ $108389^{\top}=$ LMG $22506^{\top}$ ) and Leucobacter chromiireducens subsp. solipictus subsp. nov. (type strain TAN $31504^{\top}=$ DSM $18340^{\top}=$ ATCC BAA-1336 ${ }^{\top}$ ).
\end{abstract}

The original description of Leucobacter chromiireducens (Morais et al., 2004) as a novel species of the genus Leucobacter and the validation of the species name (Morais et al., 2005) have been published previously. This work describes a strain isolated from the nematode Caenorhabditis elegans, which appears to be the first pigmented member of the genus Leucobacter, and presents a detailed comparison of the newly isolated organism with its closest phylogenetic relative.

Strain TAN $31504^{\mathrm{T}}$ was isolated from infected C. elegans that unexpectedly were found to have accumulated yellowpigmented bacteria within their translucent bodies when feeding on cream-coloured lawns of Salmonella enterica

\section{Abbreviation: DAB, 2,4-diaminobutyric acid.}

The GenBank/EMBL/DDBJ accession number for the 16S rRNA gene sequence of strain TAN $31504^{\top}$ is DQ845457.

Transmission electron micrographs of cells of strain TAN $31504^{\top}$ and a neighbour-joining tree based on $16 \mathrm{~S}$ rRNA gene sequences showing the relationship of strain TAN $31504^{\top}$ to members of the genus Leucobacter and other reference organisms are available as supplementary figures with the online version of this paper. serovar Typhimurium SL1344. Three infected nematodes were disrupted within a small aliquot of Luria-Bertani (LB) medium and subsequently plated for single colonies on LB agar. Following 2 days incubation at $25{ }^{\circ} \mathrm{C}$, colonies of the contaminant(s) were easily discernible from SL1344 by their yellow pigmentation. A single yellow colony was restreaked onto solid media for purity verification, and was confirmed to be axenic. The LB medium comprised: $10 \mathrm{~g}$ tryptone, $5 \mathrm{~g}$ yeast extract, $10 \mathrm{~g} \mathrm{NaCl}$, in $1 \mathrm{l} \mathrm{H}_{2} \mathrm{O}$; pH 7 . The type strain of L. chromiireducens (LMG 22506 ${ }^{\mathrm{T}}$ ) was obtained from the BCCM/LMG, Laboratorium voor Microbiologie, Universiteit Gent, Belgium.

Experiments were performed at least twice; standard errors of the mean are reported only for results obtained from three or more replicates. Cells were grown in the presence of approximately $25 \mu \mathrm{mol} \mathrm{m} \mathrm{m}^{-2} \mathrm{~s}^{-1}$ white light in either liquid or on solid (1.5\% agar) LB medium under aerobic conditions at $25{ }^{\circ} \mathrm{C}$, unless otherwise indicated. Optical densities were measured at $600 \mathrm{~nm}$. Growth rate studies were performed with $30 \mathrm{ml}$ liquid cultures inoculated with $30 \mu \mathrm{l}$ saturated (optical density at $600 \mathrm{~nm}=\sim 3.0$ ) cultures grown overnight at $25{ }^{\circ} \mathrm{C}$ in $250 \mathrm{ml}$ Pyrex Erlenmeyer 
flasks shaken at approximately 250 r.p.m. The $\mathrm{pH}$ range for growth was determined in liquid medium that was adjusted to $\mathrm{pH} 5$ using glacial acetic acid, to $\mathrm{pH} 5.5$ and 6 with MES, pH 6.5 with MOPS, pH 7.5 and 8 with HEPES, and pH 8.5 and 9 with Tris base. Halotolerance was examined in liquid cultures containing $\mathrm{NaCl}$ at concentrations of 0 $10 \%(\mathrm{w} / \mathrm{v} ; 1 \%$ increments). For growth in the presence of toxic metals or antibiotics (excluding fosmidomycin and mevinolin), solid medium was supplemented to the final concentrations indicated in Table 1. The effects of the isoprenoid synthesis inhibitors fosmidomycin and mevinolin were assessed in liquid culture (Trutko et al., 2005). The ability to reduce hexavalent chromium and to exhibit $\beta$-galactosidase activity was determined as described by Greenberg et al. (1998) and Miller (1972). A GP2 MicroPlate (Biolog) was used, according to the manufacturer's instructions, to characterize the utilization of the 95 carbon sources specified in Table 1. The GP2 MicroPlate reactions were scored visually after $24 \mathrm{~h}$ incubation at $25{ }^{\circ} \mathrm{C}$. All wells that developed a noticeable purple colour were scored as positive for utilization of the substrate harboured. Wells that remained colourless were scored as negative. The well reactions were characterized as follows: dark purple, strong; light purple, moderate; faint purple, weak; colourless, negative (Table 1). The ability to ferment carbohydrate was determined after 7 days incubation at $25{ }^{\circ} \mathrm{C}$ in liquid $\mathrm{LB}$ medium plus the $\mathrm{pH}$ indicator phenol red. Collection of gas within a Durham tube and/or the generation of an acidic $\mathrm{pH}$ within the media was taken to indicate carbohydrate fermentation. The absence of bubbles in the Durham tube and an unchanged or increased $\mathrm{pH}$ indicated a negative test result for fermentation. The test for anaerobic growth in LB medium was performed in $10 \mathrm{ml}$ anaerobic jars with rubber septa (Sigma) that were evacuated with hydrogen gas and then incubated at $25{ }^{\circ} \mathrm{C}$ for 7 days. Standard methods were used to assess all other biochemical characteristics (Gerhardt et al., 1981). Cell morphology and motility were determined by using phase-contrast microscopy and negative staining transmission electron microscopy (see Supplementary Fig. S1, available in IJSEM Online). Swimming, swarming and twitching motility was further assessed with motility agar. Pigment accumulation was examined under varied light quality using LEDs for specific wavelengths (www.superbrightleds.com). Pigment was extracted with 100-200 $\mu \mathrm{l}$ methanol at $65{ }^{\circ} \mathrm{C}$ from wet cell pellets generated from $1.5 \mathrm{ml}$ saturated overnight cultures. A Plasmid Mini kit (Qiagen) was used for the detection of endogenous plasmids.

The peptidoglycan and cell-wall sugars were isolated and the types and corresponding structures determined (MacKenzie, 1987; Schleifer \& Kandler, 1972; Schleifer, 1985; Rhuland et al., 1955; Staneck \& Roberts, 1974). Briefly, purification of the cell wall and preparation of the cell-wall hydrolysates were done according to the methods of Schleifer \& Kandler (1972). The N-terminal amino acid of the interpeptide bridge was determined by dinitrophenylation as described by Schleifer (1985). For the cellular fatty acid profile, fatty acid methyl esters were prepared, separated and identified using the MIDI Sherlock Microbial Identification System (Microbial ID, Inc.) as described by Vandamme et al. (1992). Analyses of respiratory quinones and polar lipids were carried out as described by Tindall $(1989,1990)$.

Isolation and purification of chromosomal DNA were performed as described by Cashion et al., (1977) and Visuvanathan et al. (1989). The protocol used for the determination of the DNA G+C content by HPLC was adapted from Tamaoka \& Komagata (1984) and the deoxyribonucleotides analysed by HPLC were generated according to the method of Mesbah \& Whitman (1989). The percentage DNA-DNA relatedness was determined using the methods described by De Ley et al. (1970), with the modifications detailed by Huß et al. (1983).

Genomic DNA was isolated and the 16S rRNA gene amplified essentially as described by Ausubel et al. (1989). The PCR product was sequenced and analysed by Sequetech Corporation. CLUSTAL W (Thompson et al., 1994) was used for the alignment of sequences and the generation of pairwise alignment scores (Wilbur \& Lipman, 1983). SEQBOOT, DNADIST, NEIGHBOR and CONSENSE of the PHYLIP package (Felsenstein, 2006) were used to produce the phylogenetic consensus tree (see Supplementary Fig. S2, in IJSEM Online).

Strain TAN $31504^{\mathrm{T}}$ grew aerobically, but not under anaerobic conditions. Cells did not ferment any of the carbon sources present in LB medium, but could produce basic ions from the metabolism of LB medium substrates, generating a $\mathrm{pH}$ of $>9.6$ in spent media. The utilizable substrates and the $\mathrm{pH}$ and growth temperature ranges of strain TAN $31504^{\mathrm{T}}$ are given in Table 1. The optimum growth rate of exponentially growing cultures occurred between 25 and $32{ }^{\circ} \mathrm{C}$. No growth was observed after 30 days at $4{ }^{\circ} \mathrm{C}$, but was readily apparent after 7 days at $10{ }^{\circ} \mathrm{C}$. A notable decrease in growth occurred at temperatures above $34{ }^{\circ} \mathrm{C}$, with marginal growth occurring at $37^{\circ} \mathrm{C}$ and no growth at $40{ }^{\circ} \mathrm{C}$. Cultivation temperature affected pigment accumulation and the number of colony forming units persisting in stationary phase cultures. More colonies were generated from cultures grown to saturation at $25-28{ }^{\circ} \mathrm{C}$ than at either 15 or $34{ }^{\circ} \mathrm{C}$. Collectively, the results indicated that strain TAN $31504^{\mathrm{T}}$ grew best at $25{ }^{\circ} \mathrm{C}$; this growth temperature was used in subsequent experiments.

Detailed characteristics of strain TAN $31504^{\mathrm{T}}$ are given in the species description. Briefly, cells grown in liquid culture tended to be shorter rods than cells grown on solid medium (see Supplementary Fig. S1, in IJSEM Online). In liquid culture, the cell span was restricted to no more than two cell lengths. On solid media, cells formed chains of short and long rods that varied from two up to, and less frequently exceeding, six cell lengths. Cells were nonmotile. Neither flagella nor pili were detected in electron micrographs taken at $>112000$ times magnification of 
Table 1. Diagnostic and differential characteristics that support a subspecies relationship between strain $\mathrm{TAN}^{31504^{\top}}$ and L. chromiireducens LMG $22506^{\top}$

Both strains are negative for the utilization of $\alpha$-cyclodextrin, $\beta$-cyclodextrin, dextrin, glycogen, inulin, mannan, $N$-acetyl-D-glucosamine, $N$-acetyl$\beta$-D-mannosamine, amygdalin, L-arabinose, D-arabitol, arbutin, D-cellobiose, D-fructose, L-fucose, D-galactose, D-galacturonic acid, gentiobiose, Dgluconic acid, $\alpha$-D-glucose, myo-inositol, $\alpha$-D-lactose, lactulose, maltose, maltotriose, D-mannitol, D-mannose, D-melezitose, methyl $\alpha$-D-galactoside, 3-methyl D-glucose, methyl $\alpha$-D-glucoside, methyl $\beta$-D-glucoside, methyl $\alpha$-D-mannoside, palatinose, D-raffinose, L-rhamnose, D-ribose, salicin, sedoheptulosan, D-sorbitol, stachyose, sucrose, D-tagatose, trehalose, turanose, xylitol, D-xylose, $\alpha$-hydroxybutyric acid, $\beta$-hydroxybutyric acid, $\gamma$ hydroxybutyric acid, $\alpha$-ketoglutaric acid, $\alpha$-ketovaleric acid, lactamide, D-lactic acid, L-lactic acid, D-malic acid, L-malic acid, succinic acid monomethyl ester, propionic acid, pyruvic acid, succinic acid, $\mathrm{N}$-acetyl-L-glutamic acid, D-alanine, L-asparagine, L-pyroglutamic acid, 2,3butanediol, uridine, adenosine 5'-monophosphate, thymidine 5'-monophosphate, uridine 5'-monophosphate, D-fructose 6-phosphate, $\alpha$-Dglucose 1-phosphate, D-glucose 6-phosphate and DL- $\alpha$-glycerol phosphate. Both strains had identical profiles for all other biochemical tests described in the text that are not listed here.

\begin{tabular}{|c|c|c|}
\hline Characteristic & Strain TAN $31504^{\mathrm{T}}$ & L. chromiireducens LMG $22506^{\mathrm{T}}$ \\
\hline \multicolumn{3}{|l|}{ Chemotaxonomic } \\
\hline DNA G $+\mathrm{C}$ content $(\mathrm{mol} \%)$ & 69.5 & $66.7^{\star}$ \\
\hline Menaquinone MK-11 (\% of total) & 62 & $80^{*}$ \\
\hline Menaquinone MK-10 (\% of total) & 38 & $20^{*}$ \\
\hline \multicolumn{3}{|l|}{ Cellular fatty acids ( $\%$ of total) } \\
\hline anteiso- $\mathrm{C}_{15: 0}$ & 66 & $54^{\star}$ \\
\hline anteiso- $\mathrm{C}_{17: 0}$ & 14 & $16^{*}$ \\
\hline iso- $\mathrm{C}_{16: 0}$ & 11 & $12^{*}$ \\
\hline linear $\mathrm{C}_{16: 0}$ & 4 & $12^{*}$ \\
\hline Polar lipids $\dagger$ & DPG, PG, unknown glycolipid & NA \\
\hline $\begin{array}{l}\text { Peptidoglycan cell-wall amino acid ratio } \\
\text { DAB : Ala: Thr: Gly: Glu (\%) } \ddagger\end{array}$ & $0.5: 1.8: 0.6: 1: 1$ & $1: 2.1: 0.7: 1.4: 1.1^{*}$ \\
\hline \multicolumn{3}{|l|}{ Metabolic substrates $₫$} \\
\hline Tween 80 & Moderate & Strong \\
\hline Acetic acid & None & Weak \\
\hline Succinamic acid & Weak & None \\
\hline L-Alanyl glycine & Moderate & Strong \\
\hline Glycyl L-glutamic acid & Moderate & Strong \\
\hline Glycerol & Strong & None \\
\hline Adenosine & None & Strong \\
\hline $2^{\prime}$-Deoxyadenosine & None & Moderate \\
\hline Inosine & None & Weak \\
\hline Thymidine & None & Moderate \\
\hline \multicolumn{3}{|l|}{ Growth in the presence of:\| } \\
\hline 50-300 $\mu \mathrm{g}$ streptomycin $\mathrm{ml}^{-1} \mathbf{g}$ & Resistant & Sensitive \\
\hline \multicolumn{3}{|l|}{ Toxic metals 9 \# } \\
\hline $5 \mathrm{mM}$ hexavalent chromium & + & ++ \\
\hline $10 \mathrm{mM}$ hexavalent chromium & $+1-$ & ++ \\
\hline $1 \mathrm{mM}$ arsenite & + & ++ \\
\hline $10 \mathrm{mM}$ arsenite & - & ++ \\
\hline $9 \% \mathrm{NaCl}(\mathrm{w} / \mathrm{v})^{\star *}$ & No growth & Poor growth \\
\hline $\mathrm{pH}$ range ${ }^{\star *}$ & $5.5-9$ & $5-9$ \\
\hline pH optimum ${ }^{* *}$ & $7.5-8.5$ & $7^{*}$ \\
\hline Temperature range $\left({ }^{\circ} \mathrm{C}\right) \dagger \dagger$ & $10-37$ & $4-37$ \\
\hline Temperature optimum $\left({ }^{\circ} \mathrm{C}\right)^{\star *}$ & $25-32$ & $28^{*}$ \\
\hline \multicolumn{3}{|l|}{ Other phenotypic characteristics $\|$} \\
\hline Pigmentation at $\leqslant 25{ }^{\circ} \mathrm{C}$ & Yellow, light-induced & None \\
\hline Bacterial lawn quality & Extremely hydrophobic & Moderately hydrophobic \\
\hline Growth rate (doubling time) (min) & $102.3 \pm 6.8$ & $80.3 \pm 6.5$ \\
\hline
\end{tabular}

${ }^{*}$ Data from Morais et al. (2004).

$\dagger$ DPG, Diphosphatidylglycerol; PG, phosphatidylglycerol; NA, not available.

$\ddagger$ The B2 $\delta$-type variant peptidoglycan structure of both strains is characterized by the cell-wall diamino acid L-DAB.

$\S$ GP2 MicroPlate colorimetric assay for utilization of substrate; reactions scored as strong, moderate, weak or none (negative). Both strains were 
Table 1. cont.

scored as moderate on pyruvic acid methyl ester and were scored as strong on Tween 40, p-hydroxyphenylacetic acid, L-alaninamide, L-alanine, Lglutamic acid, L-serine and putrescine.

IIGrowth conditions and experimental procedures are indicated in the text.

G Growth was assessed after 5 days incubation at $25^{\circ} \mathrm{C}$.

\#Growth scored as ++ , good; + , moderate; $+/-$, poor; - , none. Both strains were scored as good on $1 \mathrm{mM}$ hexavalent chromium and $80 \mu \mathrm{M}$ cadmium; only strain LMG $22506^{\mathrm{T}}$ exhibited the ability to reduce hexavalent chromium.

${ }^{*}$ Growth rates were assessed during exponential growth phase (optical density at $600 \mathrm{~nm}=0.2-1.0$ ). Both strains grew well in $3 \% \mathrm{NaCl}$ and exhibited moderate growth in $6 \% \mathrm{NaCl}$.

$\dagger \uparrow$ Temperature range for growth was assessed on solid LB medium.

liquid or solid grown cells; however, in electron micrographs of both culture types an extracellular material joining cells to one another was observed (Supplementary Fig. S1 in IJSEM Online). Lawns of cells generated on LB agar were extremely hydrophobic and formed a hardened gel-like film with extended incubation periods.

Strain TAN $31504^{\mathrm{T}}$ expressed a yellow light-inducible pigment that was excluded from crude cytosolic fractions and was methanol soluble. The absorption spectrum of the methanol-solubilized pigment suggested that it was the $\mathrm{C}_{40}$-carotenoid neurosporene (Lee \& Schmidt-Dannert, 2002; Trutko et al., 2005). Carotenogenesis was dependent on light quality and temperature. Pigmentation occurred in full spectrum white light, $5-10 \mu \mathrm{mol} \mathrm{m} \mathrm{m}^{-2} \mathrm{~s}^{-1}$ blue light and $6-10 \mu \mathrm{mol} \mathrm{m}{ }^{-2} \mathrm{~s}^{-1}$ yellow light, but not in $10 \mu \mathrm{mol}$ $\mathrm{m}^{-2} \mathrm{~s}^{-1}$ red light. Cells grown in white light at permissive temperatures above $25{ }^{\circ} \mathrm{C}$ failed to accumulate the yellow pigment; at $10-15{ }^{\circ} \mathrm{C}$ cells accumulated more pigment and were much brighter yellow than at $20-25^{\circ} \mathrm{C}$. The isoprenoid synthesis inhibitors fosmidomycin (nonmevalonate pathway inhibitor) and mevinolin (mevalonate pathway inhibitor) affected both the growth rate and pigment accumulation of strain TAN $31504^{\mathrm{T}}$. Fosmidomycin at $2.0 \mathrm{mM}$ caused a significant decrease in growth rate, but allowed cells to retain pigment. Mevinolin at $1.0 \mathrm{mM}$ also failed to cause a complete loss of pigmentation and did not reduce the quantities of cell mass accumulated to amounts below those achieved in $0 \mathrm{mM}$ mevinolin cultures. Significant reductions in both growth rate and pigment accumulation were achieved in LB containing a combination of $0.5 \mathrm{mM}$ fosmidomycin and $0.5 \mathrm{mM}$ mevinolin, suggesting that strain TAN $31504^{\mathrm{T}}$ possessed both types of isoprenoid biosynthetic pathway (Takagi et al., 2000; Trutko et al., 2005).

The major isoprenoid quinones of strain TAN $31504^{\mathrm{T}}$ were MK-11 (62\%) and MK-10 (38\%). The most abundant cellular fatty acids were anteiso- $\mathrm{C}_{15: 0}(66 \%)$, anteiso- $\mathrm{C}_{17: 0}$ (14\%), iso- $\mathrm{C}_{16: 0}(11 \%)$, and linear $\mathrm{C}_{16: 0}(4 \%)$. Galactose was the only cell-wall sugar detected. The polar lipids present in the strain included diphosphatidylglycerol, phosphatidylglycerol and an unknown glycolipid, which was suggested to be a diglycosyl diglyceride based on the $R_{\mathrm{f}}$ value. The DNA G $+\mathrm{C}$ content of strain TAN $31504^{\mathrm{T}}$ was $69.5 \mathrm{~mol} \%$.
The amino acids present in the cell wall of strain TAN $31504^{\mathrm{T}}$ were 2,4-diaminobutyric acid (DAB), alanine, threonine, glycine and glutamic acid in an approximate molar ratio of $0.5: 1.8: 0.6: 1.0: 1.0$. These ratios were similar to those of other Leucobacter species (Morais et al., 2004, 2006). The N-terminus of the interpeptide bridge of strain TAN $31504^{\mathrm{T}}$ was occupied by an alanine, not the threonine residue common to the previously reported $\mathrm{B} 2 \delta$ type structure (Hensel, 1984). The peptidoglycan structure was therefore determined to be a rare $\mathrm{B} 2 \delta$-type variant that was common to L. chromiireducens, Leucobacter luti and Leucobacter alluvii (Morais et al., 2004, 2006). The chemotaxonomic parameters thus far listed were all in accordance with the placement of strain TAN $31504^{\mathrm{T}}$ within the genus Leucobacter (Takeuchi et al., 1996; Lin et al., 2004; Morais et al., 2004, 2006).

A nearly complete $16 \mathrm{~S}$ rRNA gene sequence, encompassing 1508 bases, was obtained for strain TAN $31504^{\mathrm{T}}$. The sequence was aligned with those of other members of the genus Leucobacter (Takeuchi et al., 1996; Lin et al., 2004; Morais et al., 2004, 2006) and pairwise alignment scores were generated. From the comparison, the $16 \mathrm{~S}$ rRNA gene of strain TAN $31504^{\mathrm{T}}$ was most similar to that of $L$. chromiireducens, sharing approximately $99.5 \%$ sequence similarity. Using an implemented neighbour-joining method (Felsenstein, 2006; Saitou \& Nei, 1987), a phylogenetic tree was constructed from the 16S rRNA gene sequences of strain TAN $31504^{\mathrm{T}}$ and those of other Leucobacter species and various members of the family Microbacteriaceae that had been shown previously to cluster along a common phylogenetic branch (Kämpfer et al., 2000; Männistö et al., 2000; Behrendt et al., 2002). The results indicated, with a $100 \%$ bootstrap confidence level, that strain TAN $31504^{\mathrm{T}}$ belonged to the genus Leucobacter, displaying the least evolutionary distance from L. chromiireducens (see Supplementary Fig. S2 in IJSEM Online).

The level of DNA-DNA relatedness between strain TAN $31504^{\mathrm{T}}$ and L. chromiireducens LMG $22506^{\mathrm{T}}$ was assessed in duplicate DNA-DNA hybridization assays. The mean DNA-DNA relatedness for the two strains was calculated to be approximately $91 \%$. When the threshold value of $70 \%$ DNA-DNA relatedness for the definition of a bacterial species recommended by the ad hoc committee 
on reconciliation of approaches to bacterial systematics is considered (Wayne et al., 1987), strain TAN $31504^{\mathrm{T}}$ could be regarded as representing the species L. chromiireducens. To further distinguish strain TAN $31504^{\mathrm{T}}$, extensive morphological, physiological and biochemical comparisons of L. chromiireducens strain LMG $22506^{\mathrm{T}}$ and strain TAN $31504^{\mathrm{T}}$ were performed. The data obtained from the comparative studies are summarized in Table 1.

Strain TAN $31504^{\mathrm{T}}$ and L. chromiireducens LMG $22506^{\mathrm{T}}$ exhibited similar metabolic profiles (Table 1). In minor disagreement with that reported by Morais et al. (2004), strain LMG $22506^{\mathrm{T}}$ did not utilize L-rhamnose or glycerol, whereas strain TAN $31504^{\mathrm{T}}$ metabolized glycerol readily. Both strains did not produce urease or hydrolyse starch. The previous report of urease production by strain LMG $22506^{\mathrm{T}}$ (Morais et al., 2004) could be attributed to the alkalinization of the urease test growth media in the absence of urea that both strains caused. A number of other carbon sources that were reported to be weakly assimilated by strain LMG $22506^{\mathrm{T}}$ (Morais et al., 2004) were not confirmed by the use of the Biolog GP2 MicroPlate assay in three replicate experiments.

Strains TAN $31504^{\mathrm{T}}$ and LMG $22506^{\mathrm{T}}$ shared the same optimum growth temperature, a similar $\mathrm{pH}$ range and a comparable tolerance to salt (Table 1; Morais et al., 2004). Both strains lacked endogenous plasmids and were resistant to various levels of chromium, cadmium and arsenite, and a number of antibiotics (see species descriptions and Table 1). Unlike strain LMG $22506^{\mathrm{T}}$, strain TAN $31504^{\mathrm{T}}$ could not reduce hexavalent chromium to the less toxic trivalent oxidation state. Cells of strain LMG $22506^{\mathrm{T}}$ remained cream-coloured under all conditions tested, produced moderately hydrophobic lawns and exhibited a faster doubling rate than strain TAN $31504^{\mathrm{T}}$.

Phylogenetic and chemotaxonomic characterization indicated that strain TAN $31504^{\mathrm{T}}$ was distinct from $L$. chromiireducens and that the two strains represent separate subspecies. Therefore, strain TAN $31504^{\mathrm{T}}$ is proposed to represent a novel subspecies with the name Leucobacter chromiireducens subsp. solipictus subsp. nov., with the concomitant creation of Leucobacter chromiireducens subsp. chromiireducens subsp. nov.

\section{Emended description of Leucobacter chromiireducens Morais et al. 2005}

The characteristics are essentially the same as those described for the genus (Takeuchi et al., 1996), differing in the $\mathrm{G}+\mathrm{C}$ content of the DNA and in the abundance of menaquinones. Additional biochemical characteristics of the species to those reported by Morais et al. (2004) are given in Table 1. Contains two chromium-tolerant subspecies, one that is non-pigmented and can reduce hexavalent chromium to trivalent chromium and another that is pigmented and cannot reduce hexavalent chromium.

\section{Description of Leucobacter chromiireducens subsp. solipictus subsp. nov.}

Leucobacter chromiireducens subsp. solipictus (so.li.pic'tus. L. masc. n. sol the sun; L. masc. part. adj. pictus painted; L. masc. part adj. solipictus painted by the sun).

Cells are Gram-positive, aerobic, non-motile, non-sporeforming irregular rods that are $0.4-0.6 \mu \mathrm{m}$ wide and $0.8-$ $1.4 \mu \mathrm{m}$ long when grown at $25{ }^{\circ} \mathrm{C}$ in liquid LB medium and $0.5-0.7 \mu \mathrm{m}$ wide and $0.8-4.3 \mu \mathrm{m}$ long when grown at $25^{\circ} \mathrm{C}$ on solid LB agar for 1-2 days. Cells produce an extracellular material. Colonies are circular, entire, convex, small (0.5$1 \mathrm{~mm}$ in diameter), smooth, glistening, yellow-pigmented when grown in the light or cream-coloured when grown in the dark, and opaque on LB agar after 2-5 days growth at $25{ }^{\circ} \mathrm{C}$. The light-induced pigment is soluble in methanol and displays characteristic peaks in absorption at 413,436 and $466 \mathrm{~nm}$. Pigment production is dependent on light quality and temperature. Depigmentation of cells occurs in the combined presence of $0.5 \mathrm{mM}$ fosmidomycin and $0.5 \mathrm{mM}$ mevinolin. Growth occurs at $10-37{ }^{\circ} \mathrm{C}, \mathrm{pH} 5.5-9$, in LB containing $0-8 \% \mathrm{NaCl}$. Growth does not occur at 4 or $40{ }^{\circ} \mathrm{C}, \mathrm{pH} 5$ or in the presence of $\geqslant 9 \% \mathrm{NaCl}$. Optimum growth occurs between 25 and $32{ }^{\circ} \mathrm{C}$ at $\mathrm{pH}$ 7.5-8.5 in aerated LB lacking salt. After $2-5$ days incubation at $25^{\circ} \mathrm{C}$, growth can be seen on solid LB agar containing each of the following individually: $1 \mathrm{mM}$ arsenite, $80 \mu \mathrm{M}$ cadmium and $5 \mathrm{mM}$ hexavalent chromium; however, cells are unable to reduce hexavalent chromium to trivalent chromium. Cells are resistant to $50 \mu \mathrm{g}$ kanamycin $\mathrm{ml}^{-1}, 12.5 \mu \mathrm{g}$ tetracycline $\mathrm{ml}^{-1}, 10 \mu \mathrm{g}$ gentamicin $\mathrm{ml}^{-1}, 300 \mu \mathrm{g}$ streptomycin $\mathrm{ml}^{-1}$ and $20 \mu \mathrm{g}$ chloramphenicol $\mathrm{ml}^{-1}$ and sensitive to $100 \mu \mathrm{g}$ ampicillin $\mathrm{ml}^{-1}$ and $100 \mu \mathrm{g}$ rifampicin $\mathrm{ml}^{-1}$. Positive for catalase and alkaline phosphatase activities, but not for cytochrome $c$ oxidase, nitrate reductase, $\beta$-galactosidase, urease, gelatinase, amylase, cysteine desulfurase, tryptophanase, phenylalanine deaminase, haemolytic or lipase activities. Carbon source utilization profile is given in Table 1 . No endogenous plasmids are present. Cell-wall peptidoglycan contains DAB, alanine, glutamic acid, glycine and threonine. The peptidoglycan structure is a B $2 \delta$-type variant. Galactose is the only cell-wall sugar detected. Major isoprenoid quinones are MK-11 and MK-10. Major cellular fatty acids are anteiso- $\mathrm{C}_{15: 0}$, anteiso- $\mathrm{C}_{17: 0}$, iso- $\mathrm{C}_{16: 0}$ and linear $\mathrm{C}_{16: 0}$. Polar lipids include diphosphatidylglycerol, phosphatidylglycerol and an unknown glycolipid. The $\mathrm{G}+\mathrm{C}$ content of the DNA of the type strain is $69.5 \mathrm{~mol} \%$.

The type strain is TAN $31504^{\mathrm{T}}\left(=\mathrm{DSM} 18340^{\mathrm{T}}=\right.$ ATCC BAA- $1336^{\mathrm{T}}$ ), which was isolated from Caenorhabditis elegans and appeared as a contaminant. The location of isolation is designated Stanford, CA, USA.

\section{Description of Leucobacter chromiireducens subsp. chromiireducens Morais et al. 2005, subsp. nov.}

The description is essentially as given by Morais et al. (2004). In addition, growth occurs at $4{ }^{\circ} \mathrm{C}$. After $2-5$ days 
incubation at $25{ }^{\circ} \mathrm{C}$, growth can be seen on solid LB agar containing each of the following individually: $1 \mathrm{mM}$ arsenite, $80 \mu \mathrm{M}$ cadmium, $50 \mu \mathrm{g}$ kanamycin $\mathrm{ml}^{-1}$, $12.5 \mu \mathrm{g}$ tetracycline $\mathrm{ml}^{-1}, 10 \mu \mathrm{g}$ gentamicin $\mathrm{ml}^{-1}$ and $20 \mu \mathrm{g}$ chloramphenicol $\mathrm{ml}^{-1}$; cells are sensitive to $50 \mu \mathrm{g}$ streptomycin $\mathrm{ml}^{-1}, 100 \mu \mathrm{g}$ ampicillin $\mathrm{ml}^{-1}$ and $100 \mu \mathrm{g}$ rifampicin $\mathrm{ml}^{-1}$. Negative for $\beta$-galactosidase, urease, amylase, cysteine desulfurase, tryptophanase, phenylalanine deaminase, haemolytic and lipase activities. Additional characteristics of the carbon source utilization profile are given in Table 1. No endogenous plasmids are present.

The type strain is $\mathrm{L}-1^{\mathrm{T}}\left(=\mathrm{CIP} 108389^{\mathrm{T}}=\mathrm{LMG} 22506^{\mathrm{T}}\right)$.

\section{Acknowledgements}

This research was funded by a grant from the National Institutes of Health. R.E.M. was supported by the Stanford Genome Training Program (grant number T32 HG00044 from the National Human Genome Research Institute). We thank Professor Dr Hans G. Trüper for assistance in constructing the subspecies epithet. We would also like to thank Karen Dohrman and others at Microbial ID, Inc. (fatty acid profile) as well as Dr Peter Schumann (peptidoglycan analysis and DNA $\mathrm{G}+\mathrm{C}$ content determination), Dr Cathrin Spröer (DNA-DNA hybridization studies), Dr Brian J. Tindall (respiratory quinone and polar lipid analyses) and others at the DSMZ for the work they contributed.

\section{References}

Ausubel, F. M., Brent, R., Kingston, R. E., Moore, D., Seidman, J. G., Smith, J. A. \& Struhl, K. (1989). Current Protocols in Molecular Biology. New York: John Wiley and Sons, Inc.

Behrendt, U., Ulrich, A., Schumann, P., Naumann, D. \& Suzuki, K. (2002). Diversity of grass-associated Microbacteriaceae isolated from the phyllosphere and litter layer after mulching the sward; polyphasic characterization of Subtercola pratensis sp. nov., Curtobacterium herbarum sp. nov. and Plantibacter flavus gen. nov., sp. nov. Int J Syst Evol Microbiol 52, 1441-1454.

Cashion, P., Holder-Franklin, M. A., McCully, J. \& Franklin, M. (1977). A rapid method for the base ratio determination of bacterial DNA. Anal Biochem 81, 461-466.

De Ley, J., Cattoir, H. \& Reynaerts, A. (1970). The quantitative measurement of DNA hybridization from renaturation rates. Eur $J$ Biochem 12, 133-142.

Felsenstein, J. (2006). PHYLIP (phylogeny inference package), version 3.66. Distributed by the author. Department of Genome Sciences, University of Washington, Seattle, USA.

Gerhardt, P., Murray, R. G. E., Costilow, R. N., Nester, E. W., Wood, W. A., Krieg, N. R. \& Phillips, G. B. (editors) (1981). Manual of Methods for General Bacteriology. Washington, DC: American Society for Microbiology.

Greenberg, A. E., Trussell, R. R. \& Clesceri, L. S. (1998). Standard Methods for the Examination of Water and Wastewater. Washington, DC: American Public Health Association.

Hensel, R. (1984). Three murein types in coryneform bacteria isolated from activated sludge. Syst Appl Microbiol 5, 11-19.

Huß, V. A. R., Festl, K. H. \& Schleifer, K. H. (1983). Studies on the spectrophotometric determination of DNA hybridization from renaturation rates. Syst Appl Microbiol 4, 184-192.
Kämpfer, P., Rainey, F. A., Andersson, M. A., Nurmiaho Lassila, E.-L., Ulrych, U., Busse, H.-J., Weiss, N., Mikkola, R. \& Salkinoja-Salonen, M. (2000). Frigoribacterium faeni gen. nov., sp. nov., a novel psychrophilic genus of the family Microbacteriaceae. Int J Syst Evol Microbiol 50, 355-363.

Lee, P. C. \& Schmidt-Dannert, C. (2002). Metabolic engineering towards biotechnological production of carotenoids in microorganisms. Appl Microbiol Biotechnol 60, 1-11.

Lin, Y.-C., Uemori, K., de Briel, D. A., Arunpairojana, V. \& Yokota, A. (2004). Zimmermannella helvola gen. nov., sp. nov., Zimmermannella alba sp. nov., Zimmermannella bifida sp. nov., Zimmermannella faecalis sp. nov. and Leucobacter albus sp. nov., novel members of the family Microbacteriaceae. Int J Syst Evol Microbiol 54, 1669-1676.

MacKenzie, S. L. (1987). Gas chromatographic analysis of amino acids as the N-heptafluorobutyryl isobutyl esters. J Assoc Off Anal Chem 70, 151-160.

Männistö, M. K., Schumann, P., Rainey, F. A., Kämpfer, P., Tsitko, I., Tiirola, M. A. \& Salkinoja-Salonen, M. S. (2000). Subtercola boreus gen. nov., sp. nov. and Subtercola frigoramans sp. nov., two new psychrophilic actinobacteria isolated from boreal groundwater. Int $J$ Syst Evol Microbiol 50, 1731-1739.

Mesbah, M. \& Whitman, W. B. (1989). Measurement of deoxyguanosine/thymidine ratios in complex mixtures by high-performance liquid chromatography for determination of the mole percentage guanine + cytosine of DNA. J Chromatogr 479, 297-306.

Miller, J. H. (1972). Assay of $\beta$-galactosidase. In Experiments in Molecular Genetics, pp. 352-355. Edited by J. H. Miller. Cold Spring Harbor, NY: Cold Spring Harbor Laboratory.

Morais, P. V., Francisco, R., Branco, R., Chung, A. P. \& da Costa, M. S. (2004). Leucobacter chromiireducens sp. nov., and Leucobacter aridicollis sp. nov., two new species isolated from a chromium contaminated environment. Syst Appl Microbiol 27, 646-652.

Morais, P. V., Francisco, R., Branco, R., Chung, A. P. \& da Costa, M. S. (2005). Leucobacter chromiireducens sp. nov. In Validation of the Publication of New Names and New Combinations Previously Effectively Published Outside the IJSEM, List no. 102. Int J Syst Evol Microbiol 55, 547-549.

Morais, P. V., Paulo, C., Francisco, R., Branco, R., Chung, A. P. \& da Costa, M. S. (2006). Leucobacter luti sp. nov., and Leucobacter alluvii sp. nov., two new species of the genus Leucobacter isolated under chromium stress. Syst Appl Microbiol 29, 414-421.

Rhuland, L. E., Work, E., Denman, R. F. \& Hoare, D. S. (1955). The behavior of the isomers of $\alpha, \varepsilon$-diaminopimelic acid on paper chromatograms. J Am Chem Soc 77, 4844-4846.

Saitou, N. \& Nei, M. (1987). The neighbor-joining method: a new method for reconstructing phylogenetic trees. Mol Biol Evol 4, 406-425.

Schleifer, K. H. (1985). Analysis of the chemical composition and primary structure of murein. Methods Microbiol 18, 123-156.

Schleifer, K. H. \& Kandler, O. (1972). Peptidoglycan types of bacterial cell walls and their taxonomic implications. Bacteriol Rev 36, 407-477.

Staneck, J. L. \& Roberts, G. D. (1974). Simplified approach to identification of aerobic actinomycetes by thin-layer chromatography. Appl Microbiol 28, 226-231.

Takagi, M., Kuzuyama, T., Takahashi, S. \& Seto, H. (2000). A gene cluster for the mevalonate pathway from Streptomyces sp. strain CL190. J Bacteriol 182, 4153-4157.

Takeuchi, M., Weiss, N., Schumann, P. \& Yokota, A. (1996). Leucobacter komagatae gen. nov., sp. nov., a new aerobic grampositive, nonsporulating rod with 2,4-diaminobutyric acid in the cell wall. Int J Syst Bacteriol 46, 967-971. 
Tamaoka, J. \& Komagata, K. (1984). Determination of DNA base composition by reversed-phase high-performance liquid chromatography. FEMS Microbiol Lett 25, 125-128.

Thompson, J. D., Higgins, D. G. \& Gibson, T. J. (1994). CLUSTAL W: improving the sensitivity of progressive multiple sequence alignment through sequence weighting, position-specific gap penalties and weight matrix choice. Nucleic Acids Res 22, 4673-4680.

Tindall, B. J. (1989). Fully saturated menaquinones in the archaebacterium Pyrobaculum islandicum. FEMS Microbiol Lett 60, 251-254.

Tindall, B. J. (1990). A comparative study of the lipid composition of Halobacterium saccharovorum from various sources. Syst Appl Microbiol 13, 128-130.

Trutko, S. M., Dorofeeva, L. V., Evtushenko, L. I., Ostrovskii, D. N., Hintz, M., Wiesner, J., Jomaa, H., Baskunov, B. P. \& Akimenko, V. K. (2005). Isoprenoid pigments in representatives of the family Microbacteriaceae. Microbiology (English translation of Mikrobiologiia) 74, 284-289.
Vandamme, P., Vancanneyt, M., Pot, B., Mels, L., Hoste, B., Dewettinck, D., Vlaes, L., Van den Borre, C., Higgins, R. \& other authors (1992). Polyphasic taxonomic study of the emended genus Arcobacter with Arcobacter butzleri comb. nov. and Arcobacter skirrowii sp. nov., an aerotolerant bacterium isolated from veterinary specimens. Int J Syst Bacteriol 42, 344-356.

Visuvanathan, S., Moss, M. T., Standord, J. L., Hermon-Taylor, J. \& McFadden, J. J. (1989). Simple enzymatic method for isolation of DNA from diverse bacteria. J Microbiol Methods 10, 59-64.

Wayne, L. G., Brenner, D. J., Colwell, R. R., Grimont, P. A. D., Kandler, O., Krichevsky, M. I., Moore, L. H., Moore, W. E. C., Murray, R. G. E. \& other authors (1987). International Committee on Systematic Bacteriology. Report of the ad hoc committee on reconciliation of approaches to bacterial systematics. Int J Syst Bacteriol 37, 463-464.

Wilbur, W. J. \& Lipman, D. J. (1983). Rapid similarity searches of nucleic acid and protein data banks. Proc Natl Acad Sci U S A 80, 726-730. 